\title{
THE EFFECT OF TRANSACTIONAL LEADERSHIP AND INNOVATIVENESS ON BUSINESS PERFORMANCE
}

Clara A. Musah, University of Professional Studies Accra, Accra, Ghana Nathan K. Austin, University of Professional Studies Accra, Accra, Ghana

dx.doi.org/10.18374/JABE-19-3.10

\begin{abstract}
The study uses employee perceptions to help assess how high or low transactional leadership style and innovativeness impact business performance. Three hundred and thirty-three (333) employees from the telecommunication industry responded to a structured questionnaire. Data obtained was analyzed by regression and correlation making use of both inferential and descriptive statistics. The study discovered a significant positive relationship between both transactional leadership and innovativeness and business performance but of moderate strength. Transactional leadership and innovativeness also had a significant positive effect on business performance both independently and combined but the effect of innovativeness was higher than transactional leadership.
\end{abstract}

Keywords: Leadership, Transactional leadership, Innovativeness, Business Performance 